\title{
The effect of eccentric training on tissue repair in individuals with Achilles tendinopathy: a literature review
}

\author{
Rafael Virgínio de Souza', Vanessa Lara Araújo²
}

\begin{abstract}
Introduction: The tendinopathy is a common dysfunction in athletes and its numbers has increased in the last few years. Regarding tendon lesions, the Achilles tendinopathy is one of the most commons, especially among runners. There are several techniques to treat tendon lesions, such as the eccentric exercise. This exercise is widely used and discussed in the literature. Objective: To carry out a literature review in order to investigate the short and long term effects of eccentric exercise on tendon vascularization and structure in patients with Achilles tendinopathy. Methods: A literature search was performed in the PubMed, Scielo, Lilacs and PEDro databases. Results: 13 studies that measure the effects of eccentric exercises in the tendon structure were selected. Conclusion: The studies suggest that eccentric exercise can modify tendon structure in short and long term, reestablishing its healthy structure conditions.

Keywords: Eccentric exercise; Tendinosis; Tendinopathy; Achilles Tendon.
\end{abstract}

\section{INTRODUCTION}

The number of tendon injuries has increased, it is estimated that $30 \%$ to $50 \%$ of the injuries in the sport are related to tendons ${ }^{(1)}$. In tendinous lesions of the lower limbs, those that affect the Achilles tendon are among the most prevalent, especially in runners, with a prevalence from $2,0 \%$ to $18,5 \%{ }^{(2)}$. The term tendinopathy is used to describe a condition that occurs within or around tendons, which results from recurrent traumas or microtraumas ${ }^{(3,4,5,6)}$. Tendinopathy is characterized by local pain, increased tendon thickness, structural changes in the tissue and reduced activity level $(1,2,7,8)$. Thus, the term tendinopathy is commonly used to indicate structural morphological changes that interfere with the level of activity of the individual.

The etiology of Achilles tendinopathy is related to the mechanism of tissue overload, which can provoke microtraumas and the inflammatory process in the tissue ${ }^{(1,3)}$. These traumas generate a response of tissue regeneration, and when the physiological limit of tissue response is exceeded, a process of tissue degeneration is established with consequent loss of morphological integrity of the tissue ${ }^{(1,7,8)}$. The degenerate tissue loses the capacity to reestablish its integrity, further aggravating the degenerative process if the tissue overload continues ${ }^{(1,5,8)}$. Tissue overload can be caused by increased intensity, frequency and duration of activities performed that generate stress in the Achilles tendon, as well as biomechanical factors that alter the magnitude, direction and duration of forces applied to the tendon. Among the biomechanical factors of the individuals, we highlight limb length discrepancy, varus forefoot and the use of inappropriate footwear ${ }^{(1,4,9)}$. Thus, the association of several factors may generate an overload in the Achilles tendon, with consequent development of tendinopathy.

Within the context of tendinopathy, there are categories defined by histopathological analysis, among these categories we highlight tendinitis and tendinosis ${ }^{(10)}$. Tendinitis is characterized by vascular rupture, cell proliferation (neutrophils, eosinophils, macrophages, prostaglandins and leukotrienes), hemorrhage and formation of granulation tissue ${ }^{(10,11,12)}$. And Tendinosis is characterized by the tissue degeneration process in the tendon with loss of alignment of collagen fibers, disorganized tissue, increase of the fundamental substance (glycosaminoglycan and proteoglycan), increase of type III collagen and proliferation of capillaries ${ }^{(10,11,13,14)}$. Tendonitis occurs by recurrent microtraumas and generates a difficulty to response for tissue repair ${ }^{(3,4,5,6)}$. This histopathological definition is relevant for the treatment process, since acute and chronic dysfunctions require different approaches.

Treatments for Achilles tendinopathy are discussed in the literature and include the use of non-steroidal anti-inflammatory drugs (NSAIDs), eccentric and concentric exercise, glycerol tinitrate, shockwave extracorporeal therapy, ice, orthoses, injectable substances (autologous application

Corresponding author: Rafael Virgínio de Souza. Rua Sergipe, 69 - Tereza Cristina, São Joaquim de Bicas, $32920-000$ (MG) Brazil. E-mail: rafinhabb2005@yahoo.com.br

${ }^{1}$ Physiotherapist, Orthopedic Specialist from Federal University of Minas Gerais, Belo Horizonte (MG), Brazil

Full list of author information is available at the end of the article.

Financial support: The authors declare they financed this study.

Submission date 19 August 2016; Acceptance date 22 November 2016; Publication online date 2 December 2016 
of blood, platelet-rich plasma, corticosteroids and sclerosing agents) and Ultra-Sound (US) ${ }^{(13,15,16)}$. The NSAIDs associated with eccentric exercise are generally first-choice treatments, it is suggested that the improvement of results in what confers pain reduction and return activities can be in a short and long term ${ }^{(6,16,17,)}$. Shock wave therapy, ice, application of blood, plasma and anti-inflammatory drugs, on the other hand, appear to be effective only in the short term ${ }^{(10,3)}$. In addition, injections of corticosteroids may have deleterious effects on the tendon and favor its rupture ${ }^{(18,19)}$. Thus, several therapeutic modalities are used in the treatment of Achilles tendinopathy. The use of NSAIDs and eccentric exercise has obtained significant results in the short and long term, in what it confers the reduction of pain and in the return the activities.

Some research has demonstrated the effect of eccentric exercise for the treatment of tendinopathy, and most of them have demonstrated the benefit of this type of exercise in the improvement of pain ${ }^{(18,20)}$. In addition, the mechanism which this type of exercise may be beneficial has been the focus of other research investigating the immediate and long-term structural changes that occur in the tendons after subjecting them to eccentric training. Thus, the purpose of this review is to verify the effects of eccentric training in the short and long term on vascularization and tendon structure in individuals with Achilles tendinopathy.

\section{METHOD}

The work consisted in a bibliographic search in the databases: US National Library of Medicine National Institutes of Health (PubMed), Scientific Eletronic Library Online (Scielo), Literatura Latino-Americana e do Caribe (Lilacs) and Physiotherapy Evidence Database (PEDro), from
December 2014 to January 2015. The following keywords were used for the search of articles of interest to the research: eccentric exercise, 'tendinitis', 'tendinosis', 'Tendon Injuries', tendinopathy.

The inclusion criteria were: (1) Studies with humans that investigated the effects of eccentric training on structural changes of the tendon in individuals with Achilles tendinopathy, (2) Studies classified as randomized (RCT) and quasi-experimental (QE) clinical trials and (3) studies published in English, Portuguese or Spanish. Studies in animals, studies associating eccentric training with other therapies, studies that used eccentric training after surgery, and studies that did not use imaging for outcome measure were excluded. Searches were not limited to date.

\section{RESULTS}

The search strategy resulted in 5833 studies (PubMed $=3469$, PEDro $=285$, LILACS $=1790$, SCiELO= 289), which 5785 were excluded after reading the title and twelve of them were duplicates. The remaining 36 studies were identified as possible inclusion, and 19 of them were excluded after reading the abstracts. Among the 19 previously selected studies, we selected 17 of them, four of which were excluded after a complete reading, since they did not present an evaluation of the tendon structure as a measure of outcome. Thus, at the end of the search, we selected 13 studies investigating the effect of an eccentric exercise program on structural changes in the tendon in individuals with Achilles tendinopathy. We also identified that nine were randomized and four quasi-experimental trials. Information on the methods and results of these studies are given in Table 1.

Table 1. Description of selected studies.

\begin{tabular}{|c|c|c|c|c|c|}
\hline \multirow{2}{*}{ Author (date) } & \multirow{2}{*}{$\begin{array}{l}\text { Type of study and } \\
\text { sample }\end{array}$} & \multicolumn{2}{|c|}{ Intervention } & \multirow{2}{*}{ Outcome } & \multirow{2}{*}{ Result } \\
\hline & & Protocol & Duration & & \\
\hline Ram et al. (2013) & $\begin{array}{l}\text { RCT } \\
\text { - } \mathrm{G} 1 \text { (tendinopathy): } \\
\mathrm{n}=20 \\
\text { - } \mathrm{G} 2 \text { (control): } \mathrm{n}=21 \\
\text { - } \mathrm{G} 3 \text { (without } \\
\text { tendinopathy): } \mathrm{n}=7\end{array}$ & $\begin{array}{l}\text { - G1 \& G3=>PF } \\
\text { eccentric: 3x15 Load: } \\
\text { body weight } \\
\text { - G2=> No treatment }\end{array}$ & $\begin{array}{l}-12 \text { weeks } \\
-1 x / \text { day } \\
-7 x / \text { week } \\
-6 \text { weeks of follow up }\end{array}$ & $\begin{array}{l}\text { Neovascularization in } \\
\text { the Colour Doppler: US }\end{array}$ & $\begin{array}{l}\text { - } \uparrow \text { neovascularization } \\
\text { by comparing the } 19 \\
\text { and } 2 \text { o US only in G1 } \\
\text { - G2 \& G3 remained } \\
\text { unchanged }\end{array}$ \\
\hline $\begin{array}{l}\text { Horstmann et al. } \\
\text { (2013) }\end{array}$ & $\begin{array}{l}\text { RCT } \\
\text { - G1 (Vibration } \\
\text { training): } n=22 \\
\text { - G2 (eccentric): } n=18 \\
\text { - G3 (control): } n=14\end{array}$ & $\begin{array}{l}\text { - G1: Vibratory platform } \\
\text { => } 4 \text { to } 7 \text { min. } \\
\text { - G2 => FP eccentric: } 3 x \\
\text { 15 Load: body weight } \\
\text { + backpack }\end{array}$ & $\begin{array}{l}-12 \text { weeks } \\
-1 x / \text { day } \\
-3 x / \text { week }\end{array}$ & $\begin{array}{l}\text { Homegeticity, } \\
\text { paratendinitis tendinitis: } \\
\text { US }\end{array}$ & $\begin{array}{l}-\downarrow \text { Diagnoses of } \\
\text { tendinopathy at the } \\
\text { end of the follow up } \\
\text { for all outcomes in all } \\
\text { groups } \\
-\uparrow \text { Tendon } \\
\text { homogeneity in } \\
\text { both groups, with no } \\
\text { difference between } \\
\text { them }\end{array}$ \\
\hline
\end{tabular}

Legend: PF = Plantar flexion; $\uparrow=$ increased; $\downarrow=$ decreased; US = ultrasound; RCT = randomized clinical trial; QE = quasi-experimental; RM: Magnetic resonance imaging.; $\min =$ minutes; sec= seconds; G= group; ET= Echo Type; Echo type I and II tissue more organized than the structure of the tendon; Echo type III and IV tissue less organized than the structure of the tendon, more compatible with tendinopathy; DUS= Doppler ultrasonography. 
Table 1. Continued...

\begin{tabular}{|c|c|c|c|c|c|}
\hline \multirow{2}{*}{ Author (date) } & \multirow{2}{*}{$\begin{array}{c}\text { Type of study and } \\
\text { sample }\end{array}$} & \multicolumn{2}{|c|}{ Intervention } & \multirow{2}{*}{ Outcome } & \multirow{2}{*}{ Result } \\
\hline & & Protocol & Duration & & \\
\hline Grigg et al. (2012) & $\begin{array}{l}\text { RCT } \\
\text { - G1 (tendinopathy): } \\
\text { n=11 (SG: } \\
\text { Symptomatic group; } \\
\text { AG: Asymptomatic } \\
\text { group) } \\
\text { - CG (control): } \mathrm{n}=9 \\
\text { (Asymptomatic) }\end{array}$ & $\begin{array}{l}\text { - G1 e G2 =>FP } \\
\text { eccentric: } 3 \times 15 \text { Load: } \\
\text { body weight }\end{array}$ & 1 day (Immediate effect) & $\begin{array}{l}\text { Deformation, thickness } \\
\text { and echogenicity - } \\
\text { US }\end{array}$ & $\begin{array}{l}\text { - Post intervention: } \uparrow \\
\text { Deformation of the } \\
\text { tendon CG > AG > SG. } \\
\text { - } \downarrow \text { Thickness in both } \\
\text { groups after } 24 \mathrm{~h} \\
\text { - No difference in } \\
\text { tissue thickness in the } \\
3 \text { groups } \\
\text { - No change in } \\
\text { echogenicity in them }\end{array}$ \\
\hline Jonge et al. (2011) & $\begin{array}{l}\text { RCT } \\
\text { - G1 (Platelet-rich } \\
\quad \text { plasma injection + } \\
\text { eccentric): } n=25 \\
\text { - G2 (eccentric): } n=24\end{array}$ & $\begin{array}{l}\text { - G1 \& G2 => 1a week: } \\
\text { stretching; 2 } 2^{\text {a }} \text { to } 12^{\text {a }} \\
\text { week: FP eccentric: } \\
\text { 3x15 Load: body } \\
\text { weight }\end{array}$ & $\begin{array}{l}\text { - } 12 \text { week } \\
\text { - } 2 x / \text { day } \\
-7 x / \text { week } \\
\text { - } 1 \text { year of follow up }\end{array}$ & $\begin{array}{l}\text { - Tissue Organization ET } \\
\text { I II III IV: US } \\
\text { - Neovascularization: } \\
\text { DUS }\end{array}$ & $\begin{array}{l}\text {-ET I, II } \uparrow \text { in } 1 \text { year } \\
-E T \text { III, IV } \downarrow \text { in } 1 \text { year } \\
-\uparrow \text { Neovascularization } \\
\text { in both groups up to } \\
12 \text { weeks, returning } \\
\text { to levels below pre- } \\
\text { treatment in } 1 \text { year }\end{array}$ \\
\hline Vos et al. (2010) & $\begin{array}{l}\text { RCT } \\
\text { - G1 (Platelet-rich } \\
\text { plasma injection + } \\
\text { eccentric): } n=24 \\
\text { - G2 (eccentric): } n=24\end{array}$ & $\begin{array}{l}\text { - G1 \& G2 => 1a week: } \\
\text { stretching; 2 } 2 \text { to } 12^{\mathrm{a}} \\
\text { week: FP eccentric: } \\
\text { 3x15 Load: body } \\
\text { weight }\end{array}$ & $\begin{array}{l}\text { - } 12 \text { week } \\
-2 x / \text { day } \\
-7 x / \text { week } \\
-24 \text { week of follow up }\end{array}$ & $\begin{array}{l}\text { - Tissue Organization ET } \\
\text { I II III IV: US } \\
\text { - Neovascularization: } \\
\text { DUS }\end{array}$ & $\begin{array}{l}\text { - ET I, II } \uparrow \text { in } 24 \text { weeks } \\
\text { - ET III, IV } \downarrow \text { in } 24 \\
\text { weeks } \\
\text { - } \uparrow \text { Neovascularization } \\
\text { in both groups up to } \\
6 \text { weeks, returning to } \\
\text { levels pre-treatment } \\
\text { in } 24 \text { a week. }\end{array}$ \\
\hline Gärdin et al. (2009) & $\begin{array}{l}\text { QE } \\
\text { - G1 (eccentric): } n=20 \\
\text { - G2 (control): } n=4\end{array}$ & $\begin{array}{l}\text { - G1=> FP eccentric: } \\
\text { 3×15 Load: body } \\
\text { weight } \\
\text { - G2=> No treatment }\end{array}$ & $\begin{array}{l}-12 \text { week } \\
-2 x / \text { day } \\
-7 x / \text { week } \\
-4,2 \text { years of follow up }\end{array}$ & $\begin{array}{l}\text { Sign of tendinopathy } \\
\text { and tendon volume: RM }\end{array}$ & $\begin{array}{l}\text { - G1: } \downarrow \text { intratendin sign } \\
\text { after } 50 \text { months } \\
\text { - G2: } \uparrow \text { intratendin sign } \\
\text { after } 14 \text { months } \\
\text { - G1: No change in } \\
\text { volume after } 50 \\
\text { months } \\
\text { - G2: } \uparrow \text { volume after } \\
14 \text { months }\end{array}$ \\
\hline Knobloch et al. (2008) & $\begin{array}{l}\text { RCT } \\
\text { - G1 (orthosis + } \\
\text { eccentric): } n=43 \\
\text { - G2 (eccentric } \\
\text { exercise): } n=49\end{array}$ & $\begin{array}{l}\text { - G1=> orthosis + FP } \\
\text { eccentric } 3 \times 15 \\
\text { Load: body weight } \\
\text { - G2=> FP eccentric } \\
\text { 3x15 Load: body } \\
\text { weight }\end{array}$ & $\begin{array}{l}\text { - } 12 \text { week } \\
\text { - 2x/day } \\
\text { - 7x/week } \\
\text { - } 12 \text { weeks of follow up }\end{array}$ & $\begin{array}{l}\text { Microcirculation and } \\
\text { saturation of } \mathrm{O}_{2}: \text { Laser } \\
\text { Doppler and flowmetry }\end{array}$ & $\begin{array}{l}-\downarrow \text { Tendon capillary } \\
\text { movement only inG2 } \\
\text { - } \uparrow \text { Saturation of } \mathrm{O}_{2} \text { in } \\
\mathrm{G} 1 \\
-\downarrow \text { Venous pressure } \\
\text { in all portions of the } \\
\text { tendon in } \mathrm{G} 1 . \\
-\downarrow \text { in the insertion of } \\
\text { paratendon in G2 }\end{array}$ \\
\hline Petersen et al. (2007) & $\begin{array}{l}\text { RCT } \\
\text { - G1 (eccentric): } n=30 \\
\text { - G2 (orthosis): } n=21 \\
\text { - G3 (eccentric + } \\
\text { orthosis): } n=21\end{array}$ & $\begin{array}{l}\text { - G1=> FP eccentric: } \\
\text { 3x15 Load: body } \\
\text { weight. } \\
\text { - G2=> orthosis } \\
\text { - G3=> Both therapies }\end{array}$ & $\begin{array}{l}\text { - } 12 \text { week } \\
\text { - 3x/day } \\
\text { - 7x/week } \\
\text { - } 54 \text { weeks of follow up }\end{array}$ & Thickness: US & $\begin{array}{l}\text { - No } \\
\text { difference between } \\
\text { groups after treatment }\end{array}$ \\
\hline Knobloch et al. (2007) & $\begin{array}{l}\text { RCT } \\
\text { - G1(eccentric): } n=15 \\
\text { - G2 (Cryotherapy): } n=5\end{array}$ & $\begin{array}{l}\text { - G1=> FP eccentric: } \\
\text { 3x15 Load: body } \\
\text { weight } \\
\text { - G2=> Cryotherapy for } \\
10 \text { min. }\end{array}$ & $\begin{array}{l}\text { - } 12 \text { week } \\
\text { - 1x/day } \\
\text { - 7x/week }\end{array}$ & $\begin{array}{l}\text { Microcirculation: Laser } \\
\text { Doppler }\end{array}$ & $\begin{array}{l}\text { - G1: } \downarrow \text { Superficial and } \\
\text { deep blood flow in the } \\
\text { paratendon } \\
\text { - G1: } \uparrow \text { Venous } \\
\text { pressure on } \\
\text { paratendon } \\
\text { - No change in } \mathrm{O}_{2} \\
\text { saturation in them }\end{array}$ \\
\hline
\end{tabular}

Legend: PF = Plantar flexion; $\uparrow=$ increased; $\downarrow$ = decreased; US = ultrasound; RCT = randomized clinical trial; QE = quasi-experimental; RM: Magnetic resonance imaging.; $\mathrm{min}=$ minutes; sec=seconds; G= group; ET= Echo Type; Echo type I and II tissue more organized than the structure of the tendon; Echo type III and IV tissue less organized than the structure of the tendon, more compatible with tendinopathy; DUS= Doppler ultrasonography. 
Table 1. Continued...

\begin{tabular}{|c|c|c|c|c|c|}
\hline \multirow{2}{*}{ Author (date) } & \multirow{2}{*}{$\begin{array}{l}\text { Type of study and } \\
\text { sample }\end{array}$} & \multicolumn{2}{|c|}{ Intervention } & \multirow{2}{*}{ Outcome } & \multirow{2}{*}{ Result } \\
\hline & & Protocol & Duration & & \\
\hline $\begin{array}{l}\text { Nørregaard et al. } \\
(2007)\end{array}$ & $\begin{array}{l}\text { RCT } \\
\text { - G1 (eccentric): } n=18 \\
\text { - G2 (stretching): } n=17\end{array}$ & $\begin{array}{l}\text { - G1=> FP eccentric: } \\
1 \times 15 \text { 个 series for } 2 / 3 \text {. } \\
\text { Load: If pain free } \uparrow 5 \mathrm{~kg} \\
\text { - G2=> Stretching for } \\
5 \times 30 \mathrm{sec}\end{array}$ & $\begin{array}{l}\text { - } 12 \text { week } \\
\text { - 2x/day } \\
\text { - } 7 x / \text { week } \\
\text { - } 1 \text { year of follow up }\end{array}$ & Tendon thickness: US & $\begin{array}{c}-\downarrow \text { Tendon thickness at } \\
\text { the end of the follow } \\
\text { up in both groups }\end{array}$ \\
\hline Knobloch et al. (2007) & $\begin{array}{l}\mathrm{QE} \\
\mathrm{n}=59\end{array}$ & $\begin{array}{l}\text { - FP eccentric: } 3 \times 15 \\
\text { Load: body weight }\end{array}$ & $\begin{array}{l}\text { - } 12 \text { week } \\
-1 x / \text { day } \\
-7 x / \text { week }\end{array}$ & $\begin{array}{l}\text { Microcirculation: } \\
\text { Laser Doppler and } \\
\text { Spectroscopy }\end{array}$ & $\begin{array}{l}\text { - } \downarrow \text { Tendon blood flow } \\
\text { - No change in the } \mathrm{O}_{2} \\
\text { saturation. } \\
\text { - } \downarrow \text { Venous pressure in } \\
\text { the tendon. }\end{array}$ \\
\hline Ohberg et al, (2004) & $\begin{array}{l}\mathrm{QE} \\
\mathrm{n}=30\end{array}$ & $\begin{array}{l}\text { - FP eccentric: } 3 \times 15 \\
\text { Load: body weight }\end{array}$ & $\begin{array}{l}\text { - } 12 \text { week } \\
\text { - } 2 x / \text { day } \\
\text { - } 7 x / \text { week } \\
\text { - } 48 \text { weeks of follow up }\end{array}$ & $\begin{array}{l}\text { - Structure (hypoechoic } \\
\text { areas and organization } \\
\text { of fibers):US } \\
\text { - Neovascularization: } \\
\text { DUS }\end{array}$ & $\begin{array}{l}\downarrow \text { Number of } \\
\text { positive diagnosis } \\
\text { of tendinopathy } \\
\text { (hypoechoic areas and } \\
\text { disorganized tissue) } \\
\text { - } \downarrow \text { Number of vessels }\end{array}$ \\
\hline Shalabi et al. (2004) & $\begin{array}{l}\text { QE } \\
\mathrm{n}=22 \text { participants } \\
\text { - } \mathrm{G} 1 \text { (eccentric): } \mathrm{n}=22 \\
\text { tendons } \\
\text { - } \mathrm{G} 2 \text { (concentric): } \mathrm{n}=22 \\
\text { tendons }\end{array}$ & $\begin{array}{l}\text { - G1=>FP eccentric: } \\
\text { 3x15 Load: body } \\
\text { weight } \\
\text { - G2=> FP concentric }\end{array}$ & $\begin{array}{l}\text { - } 12 \text { week } \\
\text { - 1x/day } \\
\text { - 7x/week }\end{array}$ & $\begin{array}{l}\text { Volume tendon and } \\
\text { intensity of intratendon } \\
\text { sign: RM }\end{array}$ & $\begin{array}{l}\text { 个 Volume and } \\
\text { intratendon sign in both } \\
\text { groups }\end{array}$ \\
\hline
\end{tabular}

Legend: PF = Plantar flexion; $\uparrow=$ increased; $\downarrow$ = decreased; US = ultrasound; RCT = randomized clinical trial; QE = quasi-experimental; RM: Magnetic resonance imaging.; $\mathrm{min}=$ minutes; sec=seconds; G= group; ET= Echo Type; Echo type I and II tissue more organized than the structure of the tendon; Echo type III and IV tissue less organized than the structure of the tendon, more compatible with tendinopathy; DUS= Doppler ultrasonography.

\section{DISCUSSION}

The results of this review have shown that an eccentric training program performed at least once a day, three times a week, over a 12-week period, in the Achilles tendon in individuals with tendinopathy may be effective in modifying vascularization and tendon structure.

\section{Vascularization}

When analyzed by Collor Doppler, a method that visualizes the blood vessels present in the tissue, it is verified that the Tendon of Achilles of individuals with tendinopathy presents a greater number of blood vessels when compared with healthy individuals ${ }^{(21)}$. One possible explanation for the appearance of new vessels in cases of tendinopathy would be that this phenomenon is part of the tissue repair process in an injured tendon and high concentrations of glutamate and lactate in injured tendons appear to influence the appearance of new vessels ${ }^{(21,22)}$.

Three studies from this review have demonstrated that there is an increase of new vessels (neovascularization) in individuals with Achilles tendinopathy at the end of 12 weeks of eccentric training ${ }^{(23,24,25)}$. To Ohberg et al. ${ }^{(26)}$, when viewing the tissue by Color Doppller during eccentric exercise, affirms an interruption of flow during plantar flexion with normalization after rest. This process can be damaging to the vessels, especially considering that this process is repeated 180 times in the eccentric exercise program, which intensifies the number of vessels for repair. This increase in the number of vessels is seen only after 12 weeks of eccentric training, because in two studies that had follow up of 24 weeks and 12 months, it was observed a reduction in the number of vessels with a return to pre-treatment levels in 24 Months and at lower levels than pre-treatment at 12 months ${ }^{(23,25)}$. Thus, eccentric training becomes effective in increasing the number of vessels during the 12 weeks, which may favor the process of tissue repair. After 12 weeks, there is a gradual reduction in the number of vessels, which makes the injured tissue compatible with healthy tissue.

It is discussed the association of eccentric exercise and local application of platelet-rich plasma (PRP) in tendons of individuals with a diagnosis of tendinopathy, with a reduction in neovascularization and in the number of positive diagnoses of tendinopathy at the end of one year of monitoring ${ }^{(26)}$. In two studies found in this review ${ }^{(23,25)}$, there was no significant difference in the reduction of neovascularization when compared to eccentric exercise versus PRP associated with eccentric exercise performed for 12 weeks of training. In these two studies, there was a reduction in neovascularization. The explanation for use of PRP in injured tissues is given by their likely ability to provide beneficial hyperphysiological doses of growth factors to the tissue ${ }^{(3,27)}$. The use of PRP is increasing in order to aid in the repair process in tendons, although its effects are poorly understood and some studies 
have not observed a better PRP effect when compared to eccentric exercise.

The microcirculation is also altered in the Achilles tendon in individuals with tendinopathy. In three studies of this review, changes in blood flow, venous pressure and oxygen $\left(\mathrm{O}_{2}\right)$ saturation were observed by Laser Doppler and Fluxometry ${ }^{(20,28,29)}$. Knobloch et al. ${ }^{(30)}$ verified the increase of blood flow and venous pressure in athletes with tendinopathy at the insertion and middle portion of the tendon and in the paratendon when compared with the contralateral healthy side. The increase in blood flow is due to the alteration of a greater number of local vessels by the process that accompanies tendinopathy ${ }^{(20,21,22)}$. Increased venous pressure may lead to blood congestion and impair the function of the metabolism ${ }^{(31)}$.

In the studies of this review that subjected individuals to the 12-week eccentric training, blood flow and venous pressure reduction in the tendon and parathyroid gland were observed (shortly after the 12-week treatment) ${ }^{(20,28,29)}$. When compared to eccentric training versus nocturnal orthosis associated with eccentric training, blood flow reduction was greater in the eccentric training group ${ }^{(28)}$. On the other hand, the venous pressure was lower in the orthosis group associated with eccentric training ${ }^{(28)}$. One hypothesis of the use of orthosis is to provide a passive dorsiflexion, and the stretching of the muscle tendon unit may reduce the pressure on the tendon ${ }^{(32)}$. Knobloch et al. ${ }^{(20)}$, in an eccentric training protocol, also demonstrated a reduction in blood flow and venous pressure in individuals with Achilles tendinopathy. Compared with cryotherapy, eccentric training obtained better results in reducing flow and venous pressure ${ }^{(29)}$. One possible explanation is the effects that the overload of the eccentric exercise has under the tissue to modify local flow and pressure throughout the exercise protocol (28). Cryotherapy, in turn, has a local metabolic effect favoring the control of pain and inflammation ${ }^{(10,29,33)}$. Thus, according to the researchers mentioned above, eccentric exercise favors the reduction of neovascularization, which contributes to the reduction of flow and venous pressure. This change in venous pressure is beneficial for the removal of metabolic end products and reduction of blood flow in the tendon.

Regarding saturation of $\mathrm{O}_{2}$, isolated eccentric exercise did not modify this parameter. The group submitted to the use of orthosis associated with the eccentric training increased the saturation of $\mathrm{O}_{2}$ in the tendon and this increase favors the local metabolism ${ }^{(20,30)}$. As previously discussed, the use of orthosis provides stretching of the tissue through passive dorsiflexion, which may reduce pressure on the tendon ${ }^{(32)}$. Circulation in the affected tissue is of utmost importance for the reestablishment of the tendon and eccentric exercise confers a potential of reducing the number of vessels and consequently a normal flow and pressure.

\section{Tissue Structure}

In magnetic resonance imaging (MR), increases in signal intensity and tissue disorganization are observed, while in the US, hypoechoic regions are observed ${ }^{(6,15,34)}$. Studies of this review that verified the tissue structure using the US and MR (before and immediately after a session and after 12 weeks of eccentric training) reported varied results regarding tissue thickness and volume ${ }^{(35,36,37)}$.

In two studies, a reduction in tendon thickness was observed immediately after a session and after 12 weeks and in one study, there was no change $(35,36,37)$. A possible explanation for thickness variations may be due to the loss of integrity that the lesioned tissue has in its structural composition ${ }^{35,36,38)}$. The injured tissue is irregular and disorganized, which contributes to make the tissue thicker ${ }^{\text {(38). }}$ Since tissue modeling is time dependent, the eccentric load contributes to a more organized and regular tissue, which provides a reduction in the long-term thickness ${ }^{(35,37,38)}$.

As to the volume, in one study there was increase immediately after one session and in another there was no change after 50 months ${ }^{(39,40)}$. A possible explanation for the results is due to the fact that the increase of volume can be conferred by the increase of the water composition from the connection to the glycosaminoglycan and the increase of the local circulation caused by the exercise, which interferes in the volume ${ }^{(34,40)}$. The cessation of the program, in turn, may restore the structural integrity of the tissue and, as a consequence, the cell matrix compositions resemble the healthy tissue after the end of the program ${ }^{(35,41)}$.

The outcome variables volume and thickness are related to the cellular behavior at the time the image is taken and the role of exercise is to trigger changes ${ }^{(40)}$. However, these changes may be different according to the time the examination was performed, i.e., they may be different when performed immediately, in short or long term.

The increase in signal intensity seen in MR is characteristic of the high concentration of water in the extracellular matrix in the injured tissue ${ }^{(22,34,42)}$. Signal increase in the tendon was seen using MR in injured tendons in two studies both before training and immediately after an eccentric training session ${ }^{(39,40)}$. However, after 12 weeks of training at a follow-up of 50 months, the signal was reduced ${ }^{(39)}$. When compared to healthy tissues, patients with tendinopathy have a high concentration of glycosaminoglycan ${ }^{(10,11,13,14)}$.

These injured tissues have an ability to increase the water content in the extracellular matrix and when the tissue is submitted to the eccentric training protocol, this concentration of water tends to increase concomitantly with increased local circulation, evidencing an increased signal in the $\operatorname{MRI}{ }^{(6,22)}$. The restoration of the tendon structure after the eccentric training protocol is due to changes in the extracellular matrix content of water, glycosaminoglycan and collagen ${ }^{(41)}$. These changes seen in the MR are found to have a reduced signal 
strength ${ }^{(39,41)}$. Therefore, the histopathological alterations of the tissue evidenced alterations in the MRI of injured tendons. In addition, the eccentric training provided modification to a more organized and homogenous tissue of reduced thickness, with reestablishment of the extracellular content.

The reduction in the number of positive diagnoses of tendinopathy and the development of a more homogenous and organized tissue were also found at the end of 12 weeks of eccentric training ${ }^{(23,43,35,36)}$. Two studies in this review evaluated the Echo Types (ET) to verify tissue organization (REF) by the US. In this examination, the tissue is classified: (a) Echo Types I and II: more organized tissue and (b) Echo Types II and IV: more disorganized tissue. These studies observed an increase in ET I and II and reduction of ET III and IV after the 12-week period of eccentric training ${ }^{(23,26)}$. It is believed that the eccentric loading improves the alignment of the collagen fibers with increased tensile strength, stimulating the activities of the fibroblasts and, consequently, the synthesis of organized collagen ${ }^{(3,16,44)}$. The reduction of positive diagnoses accompanies the better tissue organization provided by the tensile force in which the tissue is submitted with the eccentric activity.

Although the effectiveness mechanisms of eccentric training are widely discussed in the literature, Stanish et al. (45) had already reported good results with eccentric training in individuals with tendinopathy. The protocol of three sets of 15 repetitions, with flexed and extended knee, being performed twice daily for at least 12 weeks has been commonly used in tendinopathy treatments ${ }^{(46)}$. The possible explanations about this effectiveness are the reduction of pain due to exercises that reduce symptoms, the reduction of the number of vessels that grow between the nerve endings and cause pain, the improvement of tissue resistance in relation to the load support and induction of stretching of musculotendinous junction reducing the pressure on the tendon ${ }^{(44,47,48)}$. These findings corroborate with existing data by reinforcing the choice of eccentric exercise in the treatment of tendinopathies because it has the potential to improve tissue structure.

The protocol of Alfredson et al. ${ }^{(46)}$ was performed in individuals with tendinopathy in the middle portion of the tendon. This protocol reinforces the positive effects of eccentric training on chronic lesions, where there is a degenerative process above the insertion, without the presence of inflammatory cells. However, three studies had the presence of tendinopathy diagnosed at the insertion of the tendon ${ }^{(20,21,29)}$. Therefore, future studies need to investigate the influence of the local of tendinopathy (middle portion versus insertion) in the effect of eccentric training.

Although some studies are based on the protocol of Alfredson et al. ${ }^{(46)}$, the variability of eccentric training protocol and adherence of patients to the eccentric training protocol may also be an explanation for divergent outcomes found in the studies. In most of the studies were used protocols of 3 series of 15 repetitions, with variation of the position of the knee, frequency of performance (daily and weekly) and load. The results of the present study do not allow us to conclude on which parameters (knee position, frequency of performance and load) are more effective. Thus, future studies could verify the best protocol in modifying the tissue structures for tendinopathy cases in the middle portion of the tendon and at the insertion.

Some factors that may explain the divergence of results in the studies included in this review should be taken into account. Heterogeneity of the population regards the age, for example, may interfere in the tissue and the effects of intervention on it. It is well known that the repair process tends to become slower in older individuals ${ }^{(25)}$. Another important factor in the studies of this review is the period of symptomatology, since are included individuals with symptoms longer than three months, phase in which there is a degenerative and non-inflammatory characteristic. This fact shows the positive effects of the eccentric treatment in which there is a degenerative process.

It is important to emphasize that the non-interruption of physical activity during the training period could also influence the results after 12 weeks. Only three studies discontinued physical activities with return in the last four weeks of training ${ }^{(25,26,35)}$. In the rest of the studies of this review, individuals were free to continue practicing physical activity during the study period, since they would not alter the physical activity. However, the combination of eccentric exercise with activity that overloads the tendon may hinder tissue repair, since it may not be able to recover from the micro-lesions caused during eccentric training. Thus, future studies should investigate whether the practice of physical activity interferes in the positive effects of eccentric training of individuals with tendinopathy.

Randomization of participants needs to be taken into account, since the presence of non-randomized studies in this review may influence outcomes. Randomization is a powerful tool for clinical evidence, as it is able to reduce the influence of confounding factors ${ }^{(49)}$. Another interesting fact was the lack of blinding of the evaluators in some studies of this review, which may make the evaluators biased to an expected result in the outcome measures.

A limitation of the study is that the outcome measures were performed through MR, US and Colour Doppler. Studies have investigated the accuracy of imaging in diagnosing tendinopathy and reports that US and MR have excellent accuracy but reduced sensitivity to detect tendinopathy ${ }^{(34,50)}$. Although they are considered gold standards examinations for the diagnosis of tendon injuries, MR and US have the subjectivity of each evaluator who interprets the examination ${ }^{(50)}$. In this sense, it is important to develop imaging tests that can quantify more parameters, thus reducing the subjectivity of the diagnosis 
and monitoring of tendinopathy ${ }^{(34,50)}$. Finally, it is important to emphasize that the isolated imaging tests are not enough to understand the whole picture of tendinopathy, its treatment and prognosis ${ }^{(34,50)}$. The role of imaging examination is limited, since it is not directly related to the symptoms of the patient ${ }^{(50)}$. Therefore, imaging is important to visualize the structure of the tendon, but it alone is not sufficient to understand the entire clinical picture of the patient.

\section{CONCLUSION}

The results of this review have demonstrated that an eccentric training program may be effective in modifying the tendon structure in individuals with Achilles tendinopathy immediately, in a short and a long term.

\section{AUTHOR'S CONTRIBUTIONS}

RVS: Search and selection of review articles and article writing. VLA: Article writing.

\section{CONFLICT OF INTEREST}

The authors declare that they have no conflicts of interest.

\section{AUTHOR DETAILS}

2 Physiotherapist, PhD student in Rehabilitation Sciences from Federal University of Minas Gerais, Belo Horizonte (MG), Brazil.

\section{REFERENCES}

1. Jarvinen T, Kannus P, Maffulli J, Khan K. Achilles Tendon Disorders: Etiology and Epidemiology. Foot Ankle Clin. Tampere. 2005 jun; 10(2): 255-66.

2. Lopes D, Hespanhol Júnior LC, Yeung SS, Costa LO. What are the main running-related musculosketal injuries? Sports Med, São Paulo. 2014 aug; 42 (10):891-905.

3. Skjong CC, Meininger AK, Ho SS. Tendinopathy Treatment: Where is the Evidence? Clinics in Sports Medicine, Chicago. 2012 apr;31(2): p329-50.

4. Almekinders L. Tendinitis and Other Chronic Tendinopathies. American Academy of Orthopaedic Surgeons. Chapel Hill. 1998 may-jun; 6,(3): 157-64.

5. Kaux JF, Forthomme B, Goff CL, Crielaard JM, Croisier JL. Current opinions on tendinopathy. Journal of Sports Science Medicine. Liege. 2011; 10 238-53.

6. KADER D, Saxena A, Movin T, Maffulli N. Achilles tendinopathy: some aspects of basic science and clinical management. BR J Sports Med, Alberden. 2002 aug; 36 (4): 239-49.

7. Sobhani S, Dekker R, Postema K, Dijkstra PU. Epidemiology of ankle and foot overuse injuries in sports: A systematic review. Scand. J. Med. Sci. Sports, Groningen. 2013 dec; 23(6): 669-86

8. Jonge $S$, van den Berg $C$, de Vos RJ, van der Heide HJ, Weir A, Verhaar $\mathrm{JA}$, et al. Incidence of midportion Achilles tendinopathy in the general population, Br J. Sports Med, Leiden. 2011 oct; 43 (14).

9. Kannus P. Etiology and pathophysiology of cronic tendon disorders in sports. Scandinaviam Journal of Medicine \& Sience in Sports, Tampere.1997 apr; 7(2): 78-85.

10. Khan K, Cook JL, Bonar F, Harcourt P, Astrom M. Histopathology of common tendinopathies. Sports Medicine, Vancouver. 1999 jun; 27 (6).

11. Sharma $P$, Maffulli N. Biology of tendon injury: healing, modeling and remodeling. J Musculoskelet Neuronal Interact. 2006 jan; 6(2):181-190.

12. Wang J. Mechanobiology of tendon. Journal of Biomchanics, Lothrop. 2005 may; 39: 1563-1582.
13. Wilson J, Best T. Commom overuse tendon problems: A review and recommendations for treatment. Am Fam Physician, Madison, 2005;72(5): 811-818.

14. Jarvinen M, Józsa L, Kannus P. Histopathological findings in chronic tendon disorders. Scand J Med Sci Sports. Tampere. 1997 apr; 7(2).

15. Kaeding C, Best T. Tendinosis: Pathophysiology and Nonoperative Treatment. Sports Health, Columbus. 2009 aug:1(4).

16. Sussmilch-Leitch S, Collins NJ, Bialocerkowski AE, Warden SJ, Crossley KM. Physical therapies for Achilles tendinopathy: systematic review and meta-analysis. Journal of Foot and Ankle Research., Melbourn. 2012 jul;5(1): 15

17. Magnussen R Dunn WR, Thomson AB. Nonoperative treatment of midportion Achilles Tendinopathy: a systematic review, Clin. J Soport Med, Nashville. 2009 jan; 19(1): 54-64.

18. Kearney R, Parsns R, Costa M. Achilles tendinopathy management: a pilot randomised controlled trial comparing platelet-richplasma injection with an eccentric exercise loading programme. Bone Joint Res., Coventry. 2013 oct; 2(10): 227-32.

19. Rompe J, Nafe B, Furia JP, Maffulli N. Eccentric loading, shock-wave treatment, or a wait-and-see policy for tendinopathy of the main body of tendon Achillis: a randomized controlled trial. Am. J. Sports Med, Gruesntadt. 2007 jul; 37(3):374-83.

20. Knobloch K. Eccentric training in Achilles tendinopathy: is it harmful to tendon microcirculation? BR J Sports Med, Hannover. 2007 jun; 41(6).

21. Ram R, Meeuwisse W, Patel C, Wiseman DA, Wiley JP. The limited effectiveness of a home-based eccentric training for treatment Achilles tendinopathy. Clin. Invest. Med. Calgary. 2013 aug; 36(4): 197-296.

22. Ohberg L, Lorentzon R, Alfredson $\mathrm{H}$. Neovascularisation in Achilles tendons with painful tendinosis but not in normal tendons: a ultrasonographic investigation. Knee Surg. Sports Traumatol, Arthrosc., Umea. 2001jul; 9(4): 233-8.

23. de Jonge $S$, de Vos RJ, Weir A, van Schie HT, Bierma-Zeinstra SM, Verhaar $\mathrm{JA}$, et al. One year follow up of platelet-rich plasma treatment in chronic Achilles tendinopathy a double-blind randomized placebo-controlled trial. The American Journal of Sport Medicine. Rotterdam. 2011; 39 (8): 1623-29.

24. Movin T, Gad A, Reinholt FP, Rolf C. Tendon pathology in long-standing achillonynia: Biopsy Findings in 40 patients. Acta Ortop. Scand, Huddinge. 1997 apr; 68(2): 170-175.

25. de Vos RJ, Weir A, Tol JL, Verhaar JA, Weinans H, van Schie HT. NO effects of PRP on ultrasonographic tendon structure and neovascularisation in chronic midportion Achilles tendinopathy. Br. J Sports Med., Rotterdam. 2011 apr: 45(5); 387-92.

26. Ohberg L, Alfredson $\mathrm{H}$. Effects on neovascularisatioin behind the good results with eccentrix exercise in cronic midportion Achilles tendinosis? Knee Surg. Sports Traumatol, Arthrosc, Umea. 2004 sep; 12(5): 465-70.

27. Abate M, Verna S, Gregorio P, Salini V, Schiavone C. Sonographic findings during and after Platelet Rich Plasma injections in tendons. Muscle, ligaments and tendons journal. Chieti Scalo. 2014 may; 4(1):29-34.

28. Knobloch K. Eccentric exercises for the management of tendinopathy of the main body of the Achilles tendon with or without the AirHeelTM Brace. A randomized controlled trial. A: Effects on pain and microcirculation. Disability and Rehabilitation, Hannover. 2008; 30(22):1685-1691.

29. Knobloch K, Kraemer R, Jagodzinski M, Zeichen J, Meller R, Vogt PM. Eccentric Training Decreases Paratendon Capillary Blood Flow and Preserves Paratendon Oxygen Saturation in Chronic Achilles Tendinopathy. Journal of orthopaedic \& Sports Physical Therapy, Hannover. 2007 may; 37(5): 269-276.

30. Knobloch K. Achilles tendon and paratendon microcirculation in midportion and insertional tendinopathy in athletes. Am. J. Sports Med, Hannover. 2006 jan; 34,(1): 92-7.

31. Knobloch $\mathrm{K}$. The role of tendon microcirculation in Achilles and patellar tendinopathy. Journal of Orthopaedic Surgery and Research. 2008 apr; $3(18)$. 
32. Roos EM, Engström M, Lagerquist A, Söderberg B. Clinical improvement after 6 weeks of eccentric exercise in patients with midportion Achilles tendinopathy- a randomized trial with 1 year follow up. Scand. J. Med. Sci. Sports, Lund. 2004 oct; 14(5): 286-85

33. Knobloch K. Changes of Achilles midiportion tendon microcirculation after simultaneous cryoterapy and compression using a Cryo/Cuff. Am. J. Sports Med, Hannover. 2006 dec; 34(12):1953-9.

34. Weireb J. Tendon, Structure, disease, and imaging. Muscles, Ligaments and Tendons Journal, Farmington. 2014; 4(2): 66-73..

35. Grigg N, Wearing S, Smeathers J. Achilles Tendinopathy Has an Aberrant Strain Response to Eccentric Exercise. Medicine and Science in Sports and Exercise. Brisbane. 2012 jan; 44(1): 12-7.

36. Nørregaard J, Larsen CC, Bieler T, Langberg H. Eccentric exercise in treatment of Achilles tendinopathy. Scand. J Med. Sci. Med., Copenhagen. 2007 apr; 17(2): 133-8.

37. Petersen W, Welp R, Rosenbaum D. Cronic Achilles Tendinopathy: A prospective randomized Study comparing the therapeutic effect of eccentric training, the AirHeel Brace, and combination of both. The American Journal of Sports Medicine, Muenster. 2007 oct; 35(10): 165967

38. Fahlstrom M, Jonsson Per, Loretzon, A. Chronic Achilles tendon pain treated with eccentric calf-muscle training. Knee Surg Sports Traumatol Arthrosc. Umea. 2003 sep; 11(5):327-33.

39. Gardin A, Movin T, Svesson L, Shalabi A. The long-term clinical and $\mathrm{MRI}$ results following eccentric calf muscle training in chronic Achilles tendinosis. Skeletal Radiol. Stockholm. 2009 sep; 39(5): 435-42.

40. Shalabi A, Kristoffersen-Wiberg M, Aspelin P, Movin T. Immediate Achilles Tendon Reponse After Strength Training Evaluated by MRI. American College Sports Medicine, Stockholm.2004 nov; 36(11): 1841-6.
41. Shalabi A, Kristoffersen-Wilberg M, Svensson L, Aspelin P, Movin T. Eccentric Training of the gastrocnemius-soleus complex in cronic Achilles tendinopathy results in decreased tendon volume and intratendinous signal as evaluated by MRI. Am. J. Sports Med., Stockholm. 2004 may; 32(5): 1286-96

42. Shalabi A. Magnetic Resonance Imaging in Cronic Achilles Tendinopathy. Acta Radiol. Suppl., Stockholm. 2004 sep; (432): 1-45.

43. Hortsmann T, Jud H, Frohlich V, Mundermann A, Grau S. Whole- body vibration versus eccentric training or a wait-and-see approach for chronic Achilles tendinopathy: a randomized clinical trial. Journal of Orthopaedic \& Sports Physical Therapy. Bad Wiessee. 2013 nov; 43(11):794-803.

44. Langberg H, Skovgaard D, Petersen LJ, Bulow J, Kjaer M. Type collagen synthesis and degradation in peritendinous tissue after exercise determined by microdialysis in humans. Journal of Physiology, Copenhagen. 1999 nov; 15(521): 299-306.

45. Stanish W, Rubinovich M, Curwin S. Eccentric Exercise in Cronic Tendinits. Clin. Orthop. Relat Res., Nova Scotia. 1986 jul; 208: 65-8.

46. Alfredson $\mathrm{H}$, Pietila $\mathrm{T}$, Jonsson $\mathrm{P}$, Lorentzon R. Heavy-Load Eccentric Calf Muscle Training For the Treatment of Chronic Achilles Tendinosis. The American Journal of Sports Medicine. Umea. 1998 may-jun; 26(3): 360-6.

47. Alfredson H. Cronic midportion Achilles tendinopathy: an update on research and treatment. Clinics in Sports Medicine. Umea. 2003 oct; 22(4): 727-41.

48. Alfredson $\mathrm{H}$. Conservative management of Achilles tendinopathy: new ideas. Foot Ankle Clin, Umea 2005 jun; 10(2): 321-9.

49. Souza R. O que é um estudo clinico randomizado? Medicina Usp. Ribeirão Preto. 2009 may; 42 (1): 3-8.

50. Docking S, Ooi C, Connel D. Tendinopathy: Is imaging Telling us the Entired Story? Journal of orthopaedic \& Sports Physical Therapy. Victoria. 2015 sep; 45(11): 1-27. 